\title{
Effect of Elevated Temperature on Alkali Activated Slag and Fly Ash Based Geopolymer Concrete
}

\author{
Mohamed H. Agamy, Anwar M. Mohammed, Sherif F.M. Abd Elnaby and Rana S. Abd Elaziz
}

\begin{abstract}
Alkali-Activated Slag (AAS) and Fly Ash (FA) based geopolymer concrete a new blended alkali-activated concrete that has been progressively studied over the past years because of its environmental benefits superior engineering properties. Geopolymer has many favorable characteristics in comparison to Ordinary Portland Cement. Many base materials could be utilized to make geopolymer with the convenient concentration of activator solution.

In this study, the experimental program composed of two phases; phase on divided into four groups; Group one deliberated the effect of sodium hydroxide molarity and different curing condition on compressive strength. Group two studied the effect of alkali activated solution ( $\mathrm{NaOH}$ and Na2SiO3) content on compressive strength and workability.

The effect of sand replacement with slag on compressive strength and workability was explained in group three. Group four studied the effect of slag replacement with several base materials Fly Ash (FA), Ordinary Portland Cement (OPC), pulverized Red Brick (PRB), and Meta Kaolin (MK).

Phase two contains three mixtures from phase one which had the highest compressive strength. For each mixture, the fresh concrete test was air content. In addition the hardened concrete tests were the compressive strength at $3,7,28,90,180$, and 365 days, the flexural strength at 28,90, and 365 days, and the young's modulus at 28, 90, and 365 days. Moreover; the three mixtures were exposed to elevated temperature at $100 \mathrm{oC}, 300 \mathrm{oC}$, and $600 \mathrm{oC}$ to study the effect of elevated temperature on compressive and flexural strength.
\end{abstract}

Keywords: Alkali activated slag (AAS), Geopolymer concrete, Ground granulated blast furnace slag (GGBS), fly ash (FA),

\section{INTRODUCTION}

Concrete is known as a significant contributor to the emission of greenhouse gases. The cement industry is the second largest producer of the greenhouse gas [1]. Because Portland cement is the main binder in concrete construction, a search for more environmentally friendly materials is undertaken. One possible alternative is the use of alkali-activated binders using industrial by-products [2].

Revised Manuscript Received on March 22, 2020.

* Correspondence Author

Mohamed H. Agamy*, Assistant Professor, Mataria, Helwan University. Email: Mohammedhelmy@m-eng.hewan.edu.eg

Anwar M. Mohammed, Associate professor, Housing and Building National Research Center.

Sherif F.M. Abd Elnaby, president of the Egyptian Russian University and Professor of Strength and Properties of Construction Materials, Civil Engineering Dept., Mataria, Helwan University.

Rana Samy, Civil Engineer, Faculty of Engineering Tanta University.

(c) The Authors. Published by Blue Eyes Intelligence Engineering and Sciences Publication (BEIESP). This is an open access article under the CC BY-NC-ND license (http://creativecommons.org/licenses/by-nc-nd/4.0/)
The most communal industrial by-products used as binder materials are fly ash (FA) and ground granulated blast furnace slag (GGBFS). GGBFS has been widely used as a cement replacement material due to its latent hydraulic properties, while fly ash has been used as a pozzolanic material to enhance the physical, chemical and mechanical properties of cements and concretes [3].Recent research has shown that it is possible to use $100 \%$ fly ash or slag as the binder in concrete by activating them with highly alkaline solutions just like Sodium or Potassium Hydroxide and Sodium or Potassium Silicate. Mechanical, physical and micro structure of geopolymer concrete is affected by the source material composition, alkali content and liquid/solid ratio [4]. Previous research concluded that liquid sodium silicate gave the highest flexural and compressive strengths of AAS mortars. Another important factor was the concentration of the activator, followed by curing temperature, and the fineness of slag [5]. The choice of the type of activator and dosage is very important in AAS concrete with the higher dosage resulting in higher strength and the higher silicate modulus of the activator resulting in higher strength [6]. The curing temperature should be maintained in between at $40-60^{\circ} \mathrm{C}$ temperature value to avoid cracks [7]. Flexural strengths are around $10.5 \%$ of compressive strength which is slightly higher than that of OPC concrete [8]. Geopolymers are generally believed to perform better than the conventional concretes in fire, due to their ceramic-like properties [9]. However, published research in fly ash-based geopolymer is limited in the area of fire resistance and responses to elevated temperatures. Geopolymer increases in strength after elevated temperature exposure [10]. The fire resistance of geopolymer is likely to be superior to OPC concrete which loses most of its strength after elevated temperature exposure about $800^{\circ} \mathrm{C}$. This paper presents an investigation into workability (slump) and compressive strength (at 7 and 28 days) of AAS concrete with different concentration of $\mathrm{NaOH}$ (molarity) at 8M, 10M, $12 \mathrm{M}$, and $14 \mathrm{M}$ at three different curing conditions. Also, it studied the effect of using different base materials such as OPC and FA on workability and compressive strength of AAS and FA based geopolymer concrete. Moreover, studying the long term properties of AAS concrete and FA based geopolymer concrete such as compressive strength, flexural strength and the effect of elevated temperature on compressive and flexural strength.

\section{Published By:}

Blue Eyes Intelligence Engineering \& Sciences Publication 


\section{EXPERIMENTAL PROGRAM}

The experimental program was composed of two phases; phase one consisted of fifteen mixtures which were divided into three groups; group one studied the effect of sodium hydroxide molarity and different curing conditions on compressive strength at 7 days and 28 days. Group two studied the effect of sand replacement by slag on workability (slump) and compressive strength at 7days and 28days. Group three studied the effect of slag replacement by FA and OPC on workability (slump) and compressive strength at 7 days and 28 days. Phase two contained three mixtures from different group in phase one which had the highest compressive strength. For each mixture, the hardened concrete tests were implemented and included the compressive strength at 3,7 , $28,90,180$, and 365 days, the flexural strength at 28, 90, and 365 days, Moreover; the three mixtures were exposed to elevated temperature at $100^{\circ} \mathrm{C}, 300^{\circ} \mathrm{C}$, and $600^{\circ} \mathrm{C}$ to study the effect of elevated temperature on compressive and flexural strength.

\section{A. Materials}

Ground Granulated Blast Furnace Slag (GGBFS) which is a by-product of the steel industry in Egypt was used instead of cement for producing the alkali activated slag concrete (AAS). Ordinary Portland cement (OPC) CEMI 42.5N was used in some geopolymer mixes with different replacement ratios of (GGBFS). Also, fly ash (FA) was used in some geopolymer mixes with different replacement ratios of (GGBFS). Chemical compositions of cement and geopolymer source materials are illustrated in Table-I

Table-I Chemical Composition of Cement and Source Materials of AAS and FA based geopolymer concrete

\begin{tabular}{|c|c|c|c|}
\hline $\begin{array}{c}\text { Composition by } \\
\text { weight (\%) }\end{array}$ & GGBFS & OPC & FA \\
\hline $\mathbf{S i O}_{2}$ & 36 & 21.7 & 42.4 \\
\hline $\mathbf{A l}_{2} \mathbf{O}_{3}$ & 9.48 & 6.3 & 27.4 \\
\hline $\mathbf{F e}_{2} \mathbf{O}_{3}$ & 0.8 & 3.4 & 6.54 \\
\hline $\mathbf{C a O}$ & 37.7 & 64.5 & 12 \\
\hline $\mathbf{M g O}$ & 4.51 & 1.86 & 3.24 \\
\hline $\mathbf{S O}_{3}$ & 2.29 & 1.77 & 1.71 \\
\hline $\mathbf{N a}_{2} \mathbf{O}$ & 0.83 & 0.28 & 0.62 \\
\hline $\mathbf{K}_{2} \mathbf{O}$ & 0.47 & 0.54 & 0.68 \\
\hline
\end{tabular}

The alkali activator used in preparing AAS and FA based geopolymer concrete mixes consists of two solutions; sodium hydroxide $(\mathrm{NaOH})$ and sodium silicate solution $\left(\mathrm{Na}_{2} \mathrm{SiO}_{3}\right)$.

The alkali solutions were mixed with $\left(\mathrm{NaOH} / \mathrm{Na}_{2} \mathrm{SiO}_{3}\right)$ ratio $1: 3$.

All mixes were produced with potable fresh water, dolomite coarse aggregate of $10 \mathrm{~mm}$ maximum aggregate size and the fine aggregate was siliceous sand with fineness modulus of 2.9.

\section{B. Concrete mixes}

A mix ratio 1:1:2 (1 slag: 1 fine aggregate: 2 coarse aggregate) had been used to study the workability and the compressive strength at 7 and 28 days. Group one mixtures are shown in Table-II, Group two mixtures are shown in Table III and Group three mixtures are shown in Table IV.

\section{Mixing procedures}

The concrete mixing procedures used in the study are as follows. Firstly, the base material and fine aggregate were mixed dry until the mixture is thoroughly blended and is uniform in colour. Next, some of activator solution was added to the mix gradually until obtaining a homogenous mixture. After that, the coarse aggregate was added. Then, the remaining activator solution was added to the previous mix until the coarse aggregate was uniformly distributed throughout the batch. Finally, mixes were cast in the molds.

\section{Specimens curing}

For steam curing after 24 hours of casting, all specimens were de-moulded and cured in steam for 3 days at $60^{\circ} \mathrm{C}$. For oven curing the geopolymer concrete specimens were de-moulded and then heated in oven for 24 hours at a temperature of $60^{\circ} \mathrm{C}$ and for air curing, the specimens were left in air until the day of testing.

Table-II: Mixes studying the effect of sodium hydroxide molarity and different curing conditions.

\begin{tabular}{|c|c|c|c|c|c|c|}
\hline $\begin{array}{c}\text { Mix } \\
\text { Name }\end{array}$ & $\begin{array}{c}\text { Slag } \\
\left(\mathbf{k g} / \mathbf{m}^{\mathbf{3}}\right)\end{array}$ & $\begin{array}{c}\text { Fine } \\
\text { Agg. } \\
\left(\mathbf{k g} / \mathbf{m}^{3}\right)\end{array}$ & $\begin{array}{c}\text { Coarse } \\
\text { Agg. } \\
\left(\mathbf{k g} / \mathbf{m}^{\mathbf{3}}\right)\end{array}$ & $\begin{array}{c}\mathbf{N a O H} \\
\left(\mathbf{k g} / \mathbf{m}^{\mathbf{3}}\right)\end{array}$ & $\begin{array}{c}\mathbf{N a}_{2} \mathrm{SiO}_{\mathbf{3}} \\
\left(\mathbf{k g} / \mathbf{m}^{\mathbf{3}}\right)\end{array}$ & Molarity \\
\hline M1-8 & 556 & 556 & 1112 & 56 & 167 & 8 \\
\hline M2-10 & 556 & 556 & 1112 & 56 & 167 & 10 \\
\hline M3-12 & 556 & 556 & 1112 & 56 & 167 & 12 \\
\hline M4-14 & 556 & 556 & 1112 & 56 & 167 & 14 \\
\hline
\end{tabular}

Table-III: Mixes studying the effect of sand replacement with slag

\begin{tabular}{|c|c|c|c|c|c|}
\hline $\begin{array}{c}\text { Mix } \\
\text { name }\end{array}$ & $\begin{array}{c}\text { Slag } \\
\left(\mathbf{k g} / \mathbf{m}^{\mathbf{3}}\right)\end{array}$ & $\begin{array}{c}\text { Fine Agg. } \\
\left(\mathbf{k g} / \mathbf{m}^{\mathbf{3}}\right)\end{array}$ & $\begin{array}{c}\text { Coarse Agg. } \\
\left(\mathbf{k g} / \mathbf{m}^{\mathbf{3}}\right)\end{array}$ & $\begin{array}{c}\mathbf{N a O H} \\
\left(\mathbf{k g} / \mathbf{m}^{\mathbf{3}}\right)\end{array}$ & $\begin{array}{c}\mathbf{N a}_{2} \mathrm{SiO}_{\mathbf{3}} \\
\left(\mathbf{k g} / \mathbf{m}^{\mathbf{3}}\right)\end{array}$ \\
\hline S-0\% & 556 & 556 & 1112 & 56 & 167 \\
\hline S-20\% & 667 & 445 & 1112 & 56 & 167 \\
\hline S-50\% & 834 & 276 & 1112 & 56 & 167 \\
\hline
\end{tabular}

Table- IV: Mixes studying the effect of slag replacement with OPC and FA

\begin{tabular}{|c|c|c|c|c|c|c|c|}
\hline Mix. Name & $\begin{array}{c}\text { OPC } \\
\left(\mathrm{kg} / \mathrm{m}^{3}\right)\end{array}$ & $\begin{array}{c}\text { Slag } \\
\left(\mathrm{kg} / \mathrm{m}^{3}\right)\end{array}$ & $\begin{array}{l}\text { Fly ash } \\
\left(\mathrm{kg} / \mathrm{m}^{3}\right)\end{array}$ & $\begin{array}{c}\text { Fine Agg. } \\
\left(\mathrm{kg} / \mathrm{m}^{3}\right)\end{array}$ & $\begin{array}{c}\text { Coarse Agg. } \\
\left(\mathrm{kg} / \mathrm{m}^{3}\right)\end{array}$ & $\begin{array}{c}\mathrm{Na}_{2} \mathrm{SiO}_{3} \\
\left(\mathrm{~kg} / \mathrm{m}^{3}\right) \\
\end{array}$ & $\begin{array}{r}\mathrm{NaOH} \\
\left(\mathrm{kg} / \mathrm{m}^{3}\right) \\
\end{array}$ \\
\hline OPC-5\% & 28 & 528 & ------ & 556 & 1112 & 167 & 56 \\
\hline OPC-10\% & 56 & 500 & ----- & 556 & 1112 & 167 & 56 \\
\hline OPC-15\% & 83 & 473 & --------- & 556 & 1112 & 167 & 56 \\
\hline OPC-20\% & 111 & 445 & ---- & 556 & 1112 & 167 & 56 \\
\hline FA-10\% & $\ldots \ldots$ & 500 & 56 & 556 & 1112 & 167 & 56 \\
\hline FA-20\% & ----- & 445 & 111 & 556 & 1112 & 167 & 56 \\
\hline FA-50\% & ----- & 278 & 278 & 556 & 1112 & 167 & 56 \\
\hline FA-100 $\%$ & $\ldots$ & $\ldots \ldots$ & 556 & 556 & 1112 & 167 & 56 \\
\hline
\end{tabular}

\section{E. Concrete tests}

Slump test, compressive strength, and flexural strength were conducted on specimens as shown in Fig. 1.

Slump tests were conducted according to standard specification ASTM C143/C143M-03[11].
Compressive strength of the different mixes was determined experimentally on cubes $(100 \times 100 \times 100) \mathrm{mm}$.

Published By:

Blue Eyes Intelligence Engineering

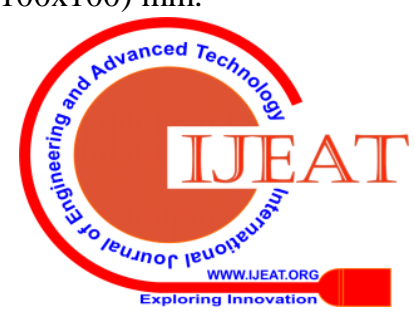

\& Sciences Publication

(C) Copyright: All rights reserved. 
The compressive strength tests were conducted according to standard specification BS EN 12390-3:2009[12].

By using beams (100x100x500)mm flexural strength tests were conducted according to standard specification ASTM C78/C78M-18[13]. For the effect of elevated temperature, three mixtures were casted into cubes $(100 \times 100 \times 100)$ $\mathrm{mm}$ and beams $(100 \times 100 \times 500) \mathrm{mm}$. The unloaded

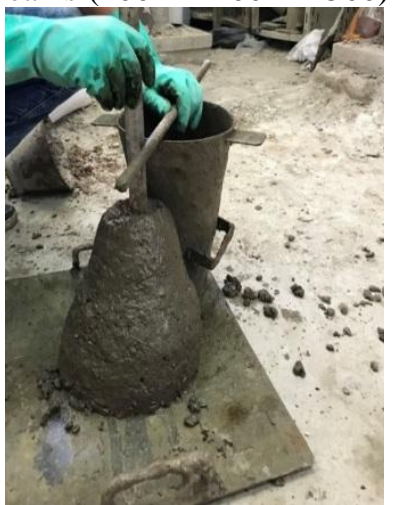

a) Slump test

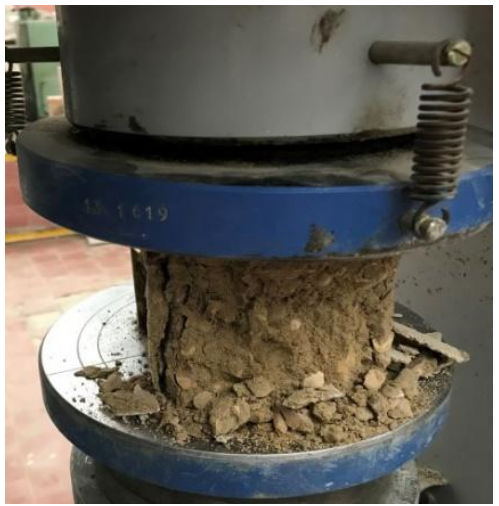

b) Compressive strength test cubes were placed in oven for $1 \mathrm{hr}$., and $2 \mathrm{hr}$., after reaching the required temperature at $100^{\circ} \mathrm{C}, 300^{\circ} \mathrm{C}, 600^{\circ} \mathrm{C}$. Half of the samples were left to be gradually cooled, where the other half were suddenly cooled by emerging in water. All samples were tested in compression and flexure strength.

Fig. 1: Concrete Mechanical Tests

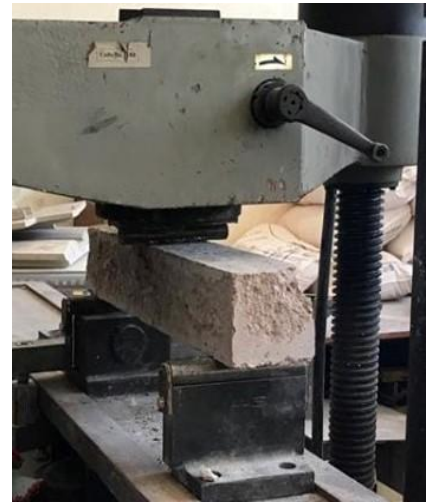

c) Flexural strength test

\section{III. - RESULTS}

\section{A. EFFECT OF MIXTURE COMPOSITION}

Table - V: shows measured slump and compressive strength of the AAS and FA based geopolymer concrete mixtures on phase one.

Table-V: Properties of Tested Specimens

\begin{tabular}{|c|c|c|c|c|c|c|c|c|}
\hline \multirow{3}{*}{ Group No. } & \multirow{3}{*}{ Mix name } & \multirow{3}{*}{$\begin{array}{c}\text { Slump } \\
(\mathbf{m m})\end{array}$} & \multicolumn{6}{|c|}{ Compressive strength (MPa) } \\
\hline & & & \multicolumn{3}{|c|}{7 days } & \multicolumn{3}{|c|}{28 days } \\
\hline & & & Air & Oven & Steam & Air & Oven & Steam \\
\hline \multirow{4}{*}{ Group 1} & M1-8 & -- & 9 & 9.2 & 15 & 10 & 11 & 17 \\
\hline & M2-10 & --- & 8 & 9 & 28 & 8.5 & 10 & 30 \\
\hline & M3-12 & --- & 10 & 11 & 32 & 11 & 11.8 & 34 \\
\hline & M4-14 & --- & 10.5 & 16.5 & 34 & 11.2 & 17 & 35 \\
\hline \multirow{3}{*}{ Group 2} & $\mathrm{~S}-0 \%$ & 50 & ---- & ---- & 32 & ---- & ---- & 34 \\
\hline & S-20\% & 60 & $\begin{array}{ll}--- \\
\end{array}$ & $\begin{array}{ll}--- \\
\end{array}$ & 35 & $\begin{array}{ll}--- \\
\end{array}$ & $\begin{array}{ll}--- \\
\end{array}$ & 42 \\
\hline & S- $50 \%$ & 80 & ---- & ---- & 31 & ---- & ---- & 33.8 \\
\hline \multirow{8}{*}{ Group 3} & FA-10\% & 70 & ---- & ---- & 34 & ---- & ---- & 37 \\
\hline & FA-20\% & 80 & $\begin{array}{l}--- \\
\end{array}$ & $\begin{array}{ll}--- \\
\end{array}$ & 38.9 & $\begin{array}{l}--- \\
\end{array}$ & $\begin{array}{l}--- \\
\end{array}$ & 42 \\
\hline & FA-50\% & 130 & ---- & ---- & 51 & ---- & ---- & 54.4 \\
\hline & FA-100\% & 210 & $\begin{array}{l}--- \\
\end{array}$ & $\begin{array}{ll}--- \\
\end{array}$ & 26.5 & ---- & $\begin{array}{l}--- \\
\end{array}$ & 29 \\
\hline & OPC-5\% & 55 & ---- & ---- & 34 & ---- & ---- & 38 \\
\hline & OPC-10\% & 60 & ---- & ---- & 37 & ---- & $\begin{array}{ll}--- \\
\end{array}$ & 42 \\
\hline & OPC-15\% & 70 & $\begin{array}{l}--- \\
\end{array}$ & ---- & 39 & ---- & ---- & 45 \\
\hline & OPC-20\% & 80 & ---- & ---- & 42 & ---- & ---- & 50 \\
\hline
\end{tabular}

- Effect of sodium hydroxide molarity and different curing conditions on compressive strength.

The effect of molarity of sodium hydroxide $(\mathrm{NaOH})$ on compressive strength of AAS concrete is shown in Table-V. Fig. $2 \& 3$ show that increasing the molarity from $8 \mathrm{M}$ to $10 \mathrm{M}$ increased the compressive strength by $76.5 \%$. Also increasing the molarity from $10 \mathrm{M}$ to $12 \mathrm{M}$ increased the compressive strength by $13 \%$. Increasing the molarity from $12 \mathrm{M}$ to $14 \mathrm{M}$ increased the compressive strength by $3 \%$. It can be noted that increasing the molarity of $\mathrm{NaOH}$ from $8 \mathrm{M}$ to $14 \mathrm{M}$ gradually increases the compressive strength of AAS concrete. M3-12 was selected as the basic mixture to study the effect of other parameters for two reasons; firstly increasing the molarity from $12 \mathrm{M}$ to $14 \mathrm{M}$ increased the compressive strength by $3 \%$, which can be regarded as a small increasing value, and the cost of alkaline liquid is economical when concentration of $\mathrm{NaOH}$ solution $12 \mathrm{M}$ compared with $14 \mathrm{M}$. Secondly, the required compressive strength was achieved [14, 15].Fig. $2 \& 3$ show that the compressive strength increased by a value ranging from $55 \%$ to $200 \%$ at steam curing compared with oven curing and the compressive strength increased by a value ranging from $7 \%$ to $50 \%$ at oven curing compared with air curing.

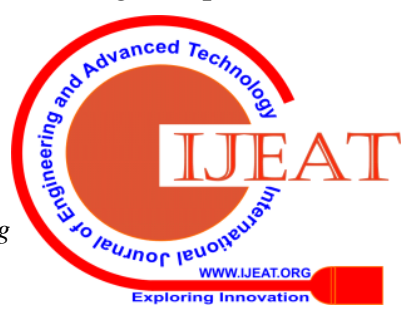


The results show that steam curing at $60^{\circ} \mathrm{C}$ for 3 days lead to the highest compressive strength for all samples, then oven curing at $60^{\circ} \mathrm{C}$ for 24 hours and the least values are related to air curing. The results are consistent with previous research [5]. From the previous results, it can be noted that the air curing values were near to the oven curing value. This may be due to insufficient duration of the $60^{\circ} \mathrm{C}$ of one day to complete the polymerization reaction. Swanepoel et al. [16] stated that combination of $60^{\circ} \mathrm{C}$ temperature and 48 hours curing time gives the optimum strength for the binder. The steam curing substantially assists the chemical reaction that occurs in the geopolymer concrete. Both curing time and curing temperature influence the compressive strength of AAS concrete. So the steam curing is selected as the basic curing to study the effect of other parameters.

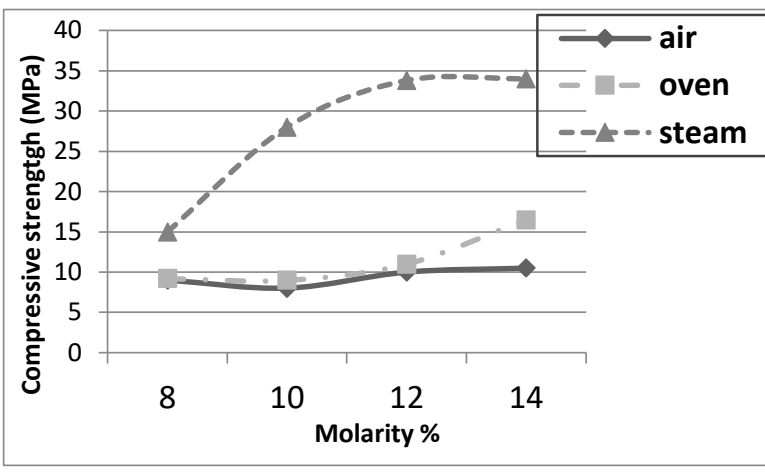

Fig. 2: Effect of sodium hydroxide molarity and different curing condition on compressive strength of mixes at 7 days.

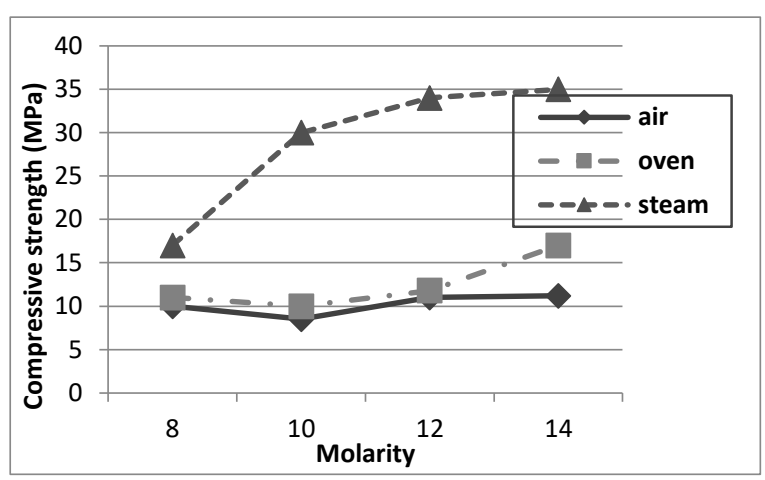

Fig. 3: Effect of sodium hydroxide molarity and different curing condition on compressive strength of mixes at 28 days.

- Effect of sand replacement by slag on compressive strength and workability.

The mixtures S-0\%, S-20\% and S-50\% have slump 50 mm, 60 $\mathrm{mm}$ and $80 \mathrm{~mm}$ respectively. It can be noted that $20 \%$ sand replacement increased the slump by $20 \%$ compared to S- $0 \%$ and $50 \%$ sand replacement increased the slump by $60 \%$ compared to S-0\% as shown in Fig. 4. Thus, increasing sand replacement by slag increased the slump.

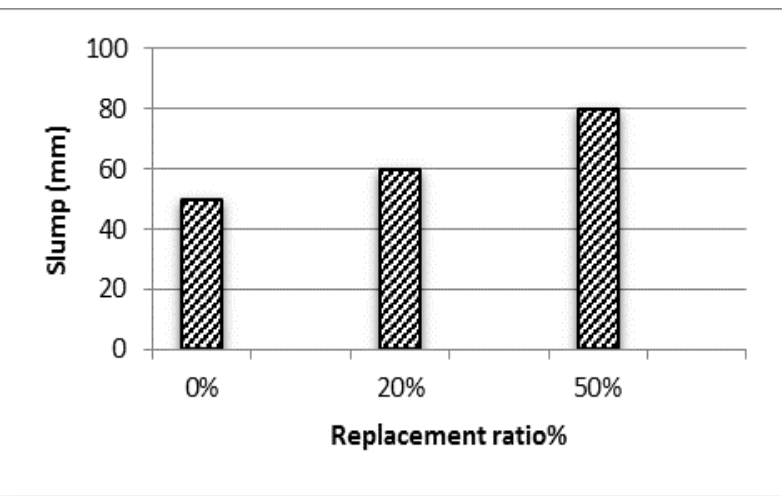

Fig.4: Effect of sand replacement by slag on slump Fig. 5 shows that $20 \%$ replacement of sand by slag , increased the compressive strength by $30 \%$ compared to the mixture without sand replacement (S-0\%), but 50\% replacement of sand by slag decreased the compressive strength by $2 \%$ compared to the mixture without sand replacement (S-0\%). At $20 \%$ replacement of sand, the rise of compressive strength may be attributed to Geopolymerization reactions and enhanced the compressive strength. At 50\% replacement of sand, the decreasing of compressive strength may be attributed to increasing the slag content when the solution was constant, improving the plasticity of the paste and denser riser structure due to filling effect. Leaving the slag as excessive inert fine particles affecting the cohesiveness of the paste.

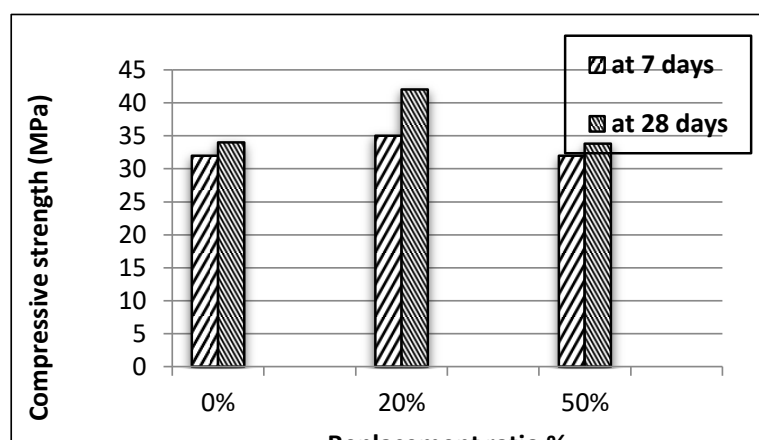

Fig.5: Effect of sand replacement by släg on compressive strength

- Effect of slag replacement by FA and OPC on compressive strength and workability.

Fig. 6 shows that the slump of the mixture by $10 \%$ fly ash increased by $40 \%$ compared to the mixture with $0 \%$ fly ash. The slump of mixture with $20 \%$ fly ash increased by $60 \%$ compared to the mixture with $0 \%$ fly ash. The slump of the mixture with $50 \%$ fly ash increased by $160 \%$ compared to mixture with $0 \%$ fly ash and the slump of the mixture with $100 \%$ fly ash increased by 320\% compared to the mixture with $0 \%$ fly ash. The increase of slump value with increase of fly ash content in the mixture is consistent with previous studies $[17,18]$ This can be attributed to the spherical shape of fly ash particles compared to the angular shape of slag particles[17].

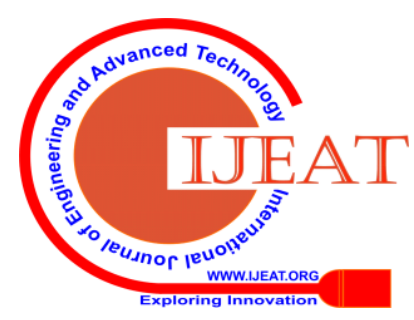




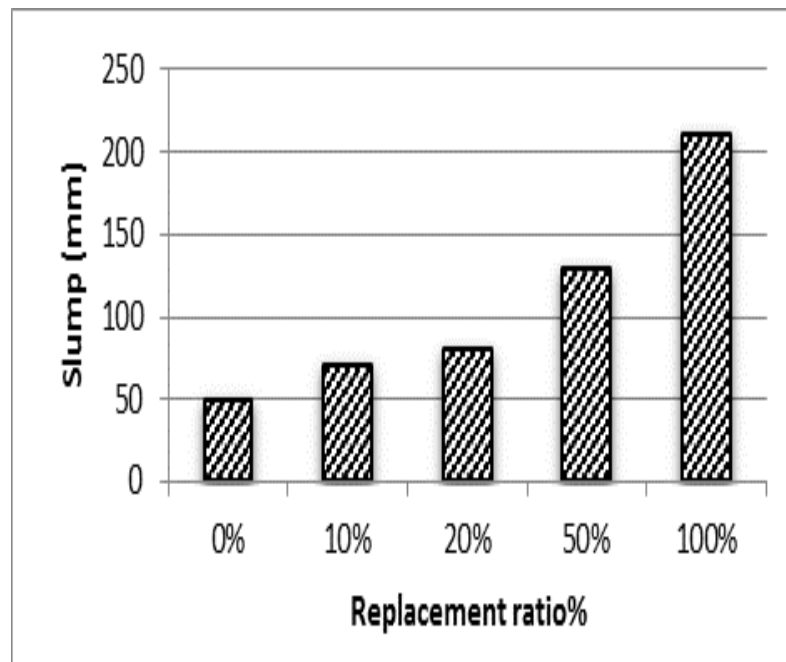

Fig. 6: Effect of slag replacement by fly ash on slump Figure 7 shows that the compressive strength of mixture with $100 \%$ fly ash decreased by $15 \%$ compared to the mixture with $0 \%$ fly ash. The compressive strength of the mixture with $50 \%$ fly ash increased by $60 \%$ compared to the mixture with $0 \%$ fly ash. The compressive strength of the mixture with $20 \%$ fly ash increased by $23.5 \%$ compared to the mixture with $0 \%$ fly ash. The compressive strength of the mixture with $10 \%$ fly ash increased by $9 \%$ compared to the mixture with $0 \%$ fly ash. The previous research showed that the compressive strength increased with increasing the amount of fly ash up to $50 \%$, then reduced again at $100 \%$ fly ash. The increase of the compressive strength may be attributed to the formation of C-A-S-H gels, which would reduce the porosity and condense the microstructure of AAS matrix [19, 20]. The reduction of compressive strength may be attributed to geopolymer containing higher fly ash content, thus highly porous structure resulting in lower compressive strength [21].

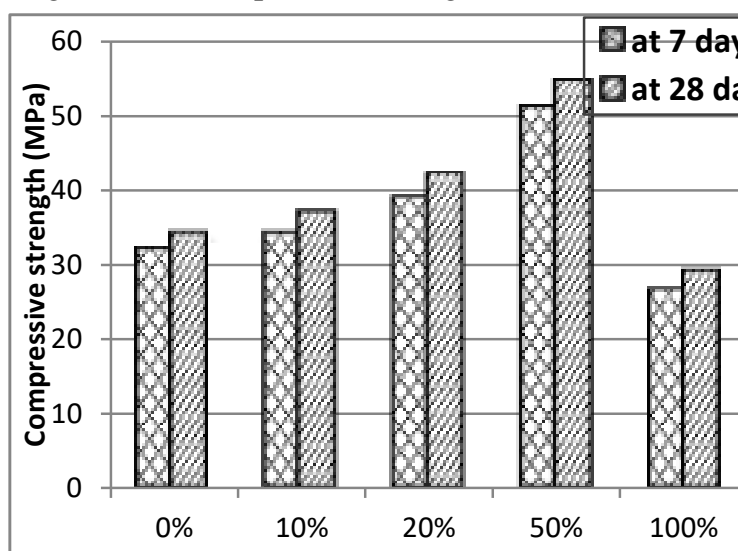

Fig. 7: Effect of slag replacement by fly ash on compressive strength

Fig. 8 shows that the slump of mixture OPC-5\% increased by $10 \%$ compared to the mixture S- $0 \%$, while the slump of mixture OPC-10 \% increased by $20 \%$ compared to the mixture S-0\%, slump of mixture OPC-15\% increased by $40 \%$ compared to the mixture $\mathrm{S}-0 \%$ and slump of mixture OPC-20\% increased by $60 \%$ compared to the mixture S- $0 \%$. Thus, the slump value increased with the increase of OPC content in the mixture.

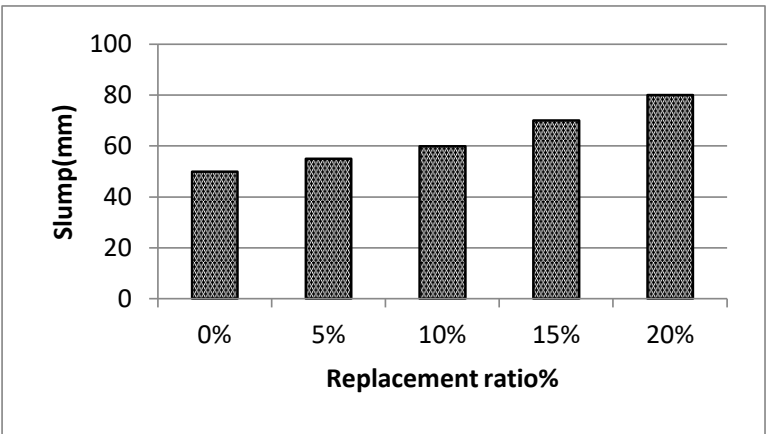

Fig. 8: Effect of slag replacement by Ordinary Portland Cement on slump

Fig. 9: shows that the replacement of slag by 5\%, 10\%, 15\% and $20 \%$ OPC increased the compressive strength by $6 \%$, $16 \%, 22 \%$, and $31 \%$ after 7 days and increase by $12 \%, 23.5 \%$, $32 \%$ and $47 \%$ respectively after 28days compared with the control mix without slag replacement. The addition of OPC modifies the products and the pore structure in hardened cementitious materials. Increasing the OPC content results in denser structure by reducing the pore size in concrete, due to GGBS reacts with calcium hydroxide to form extra C-S-H gel in the concrete matrix[22].

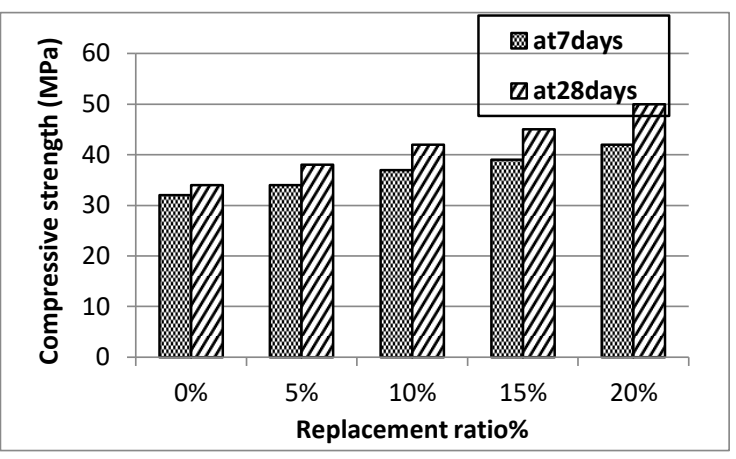

Fig. 9: Effect of slag replacement by Ordinary Portland Cement on compressive strength

B. Geopolymer concrete mixtures used in phase two Table-VI shows that the three mixtures which were selected from phase one. They had the highest compressive strength for each of the three groups considered in phase one. They were used to study the development with time of compressive strength, and the effect of elevated temperature.

Table- VI: Concrete mixtures used in phase one.

\begin{tabular}{|c|c|c|c|c|c|c|c|}
\hline Mixture & $\underset{\mathrm{kg} / \mathrm{m}^{3}}{\text { Slag }}$ & $\begin{array}{c}\text { Fly } \\
\text { ash } \\
\mathrm{kg} / \mathrm{m}^{3}\end{array}$ & $\begin{array}{c}\text { OPC } \\
\mathrm{kg} / \mathrm{m}^{3}\end{array}$ & $\begin{array}{l}\text { Fine } \\
\text { Agg. } \\
\text { kg/m }{ }^{3}\end{array}$ & $\begin{array}{c}\text { Coarse } \\
\text { Agg. } \\
\text { kg/m }\end{array}$ & $\begin{array}{c}\mathrm{NaOH} \\
\mathrm{kg} / \mathrm{m}^{3}\end{array}$ & $\begin{array}{c}\mathrm{Na}_{2} \mathrm{SiO}_{3} \\
\mathrm{~kg} / \mathrm{m}^{3}\end{array}$ \\
\hline S-20\% & 667 & --- & ---- & 445 & 1112 & 56 & 167 \\
\hline FA-50\% & 278 & 278 & ---- & 556 & 1112 & 56 & 167 \\
\hline OPC-20\% & 445 & ---- & 111 & 556 & 1112 & 56 & 167 \\
\hline
\end{tabular}

- Development of compressive strength.

Table-VII illustrates the compressive strength development of the tested three mixes. 
Effect of Elevated Temperature on Alkali Activated Slag and Fly Ash Based Geopolymer Concrete

Table- VII: Compressive strength development

\begin{tabular}{|l|c|c|c|c|c|c|}
\hline \multirow{2}{*}{ Mixture } & \multicolumn{6}{|c|}{ Compressive strength (MPa) } \\
\cline { 2 - 7 } & 3days & 7days & 28days & 90days & 180days & 365days \\
\hline S-20\% & 22 & 35 & 42 & 45 & 46 & 46 \\
\hline FA-50\% & 40 & 51 & 54.4 & 61 & 61.5 & 63 \\
\hline OPC-20\% & 29 & 42 & 50 & 54 & 55 & 56 \\
\hline
\end{tabular}

As shown in Fig. 10 for the mixture S-20\%, the compressive strength value at 3 days was $63 \%$ of the compressive strength at 7 days. The compressive strength at 7 days was $83 \%$ of the compressive strength at 28 days. The compressive strength at 90 days increased by $7 \%$ more than the compressive strength at 28 days. The increase in compressive strength after 90 days was small.

For mixture FA-50\%, the compressive strength value at 3 days was $78 \%$ of compressive strength at 7 days. The compressive strength value at 7 days was $94 \%$ of compressive strength at 28 days. The compressive strength at 90 days increased by $12 \%$ more than the compressive strength at 28 days. The increase in compressive strength after 90 days was small. For mixture OPC-20\%, the compressive strength value at 3 days was $69 \%$ of compressive strength at 7 days. The compressive strength value at 7 days was $84 \%$ of compressive strength at 28 days. The compressive strength at 90 days increased by $8 \%$ more than the compressive strength at 28 days. The increase in compressive strength after 90 days was small.

The previous results showed that the compressive strength of tested concretes increased steadily at 28 days but after that, the increasing rate of compressive strength became much slower. The chemical reaction of the geopolymer is a rapid polymerization process about $70 \%$ of its strength is gained within the first 3-4 hours of curing [23, 24].

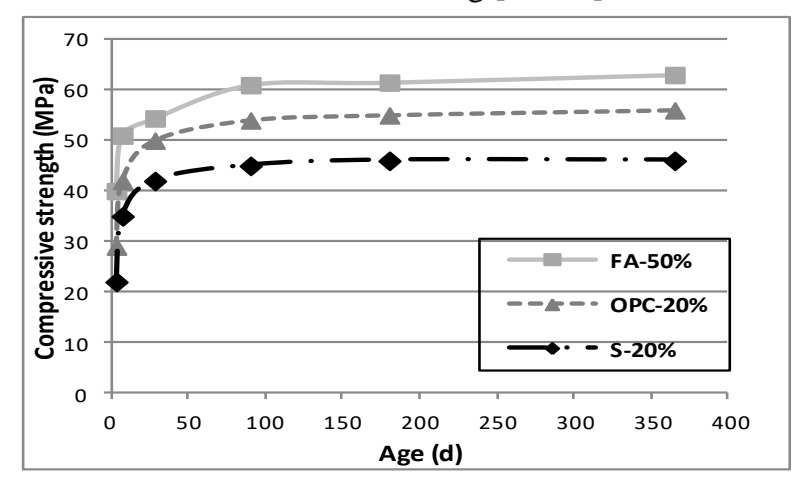

Fig.10: Compressive strength developments - Development of Flexural strength

Table-VIII illustrates the flexural strength development of the three tested mixes. As shown in Fig. 11 for mixture S-20\%, the flexural strength increased at 90days by $5 \%$ more than the flexural strength at 28 days and decreased at 365 days by $10 \%$ less than the flexural strength at 90 days. The higher amount of slag leads to micro-cracks inside the concrete which may have reduced the flexural strength of concrete at 365days [25]. For mixture FA-50\%, the flexural strength increased at 90days by $8.7 \%$ more than the flexural strength at 28days and increased at 365days by the same ratio more than the flexural strength at 90 days. For mixture OPC-20\%, the flexural strength increased at 90 days by $14 \%$ more than the flexural strength at 28 days and increased at 365 days by $4 \%$ more than the flexural strength at 90 days. It can be seen that the mixture FA-50\% has the highest value of flexural strength compared to S-20\% and OPC-20\%.
Table-VIII: Flexural strength development

\begin{tabular}{|c|c|c|c|}
\hline \multirow{2}{*}{ Mixture } & \multicolumn{3}{|c|}{ Flexural strength (MPa) } \\
\cline { 2 - 4 } & 28days & 90days & 365days \\
\hline S-20\% & 3.9 & 4.1 & 3.7 \\
\hline FA-50\% & 6.9 & 7.5 & 8 \\
\hline OPC-20\% & 4.2 & 4.8 & 5 \\
\hline
\end{tabular}

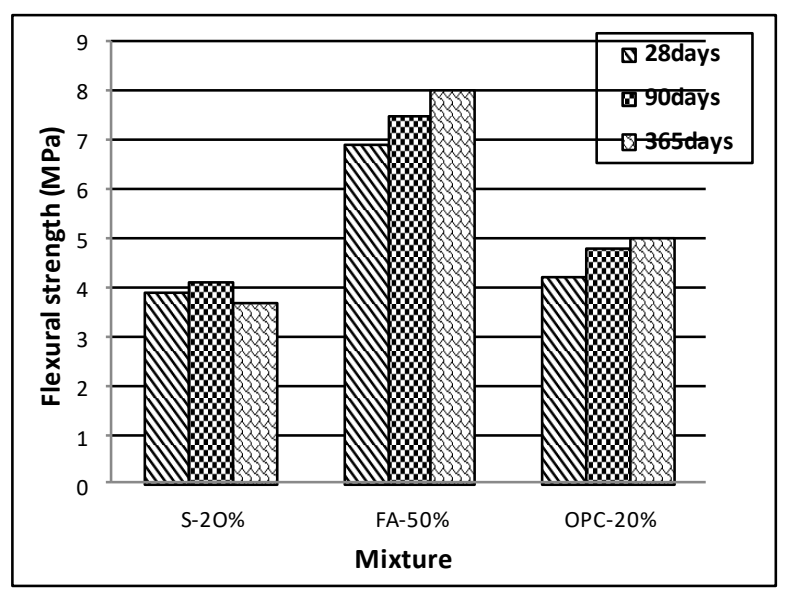

Fig.11: Flexural strength developments

- Elevated temperature effect on compressive strength

Table-X shows the effect of elevated temperature on compressive strength for S-20\%, FA-50\%, and OPC-20\%. As shown in Fig. 12, the mixture S-20\% at air cooled regime heating to $100^{\circ} \mathrm{C}$ for one and two hours led to compressive strength increase about $15 \%$ and $10 \%$, respectively. On the other hand, heating to $300^{\circ} \mathrm{C}$ for one and two hours led to compressive strength reduction of about $2 \%$ and $9.5 \%$, respectively. Moreover, heating to $600^{\circ} \mathrm{C}$ for one and two hours led to compressive strength drop of about $17 \%$ and $26 \%$ respectively. At water cooled regime heating to $100^{\circ} \mathrm{C}$ for one and two hours led to compressive strength increase of about $7 \%$ and $2 \%$, respectively. On the other hand heating to $300^{\circ} \mathrm{C}$ for one and two hours led to compressive strength loss of about $7 \%$ and $16 \%$, respectively. Moreover heating to $600{ }^{\circ} \mathrm{C}$ for one and two hours led to compressive strength reduction of about $26 \%$ and $28.5 \%$, respectively. The reduction in compressive strength at 300 and $600^{\circ} \mathrm{C}$ may be due to the thermal discordance between aggregates and geopolymer matrix which led to formation of internal stresses then cracks which deteriorated the concrete. [26, 27].

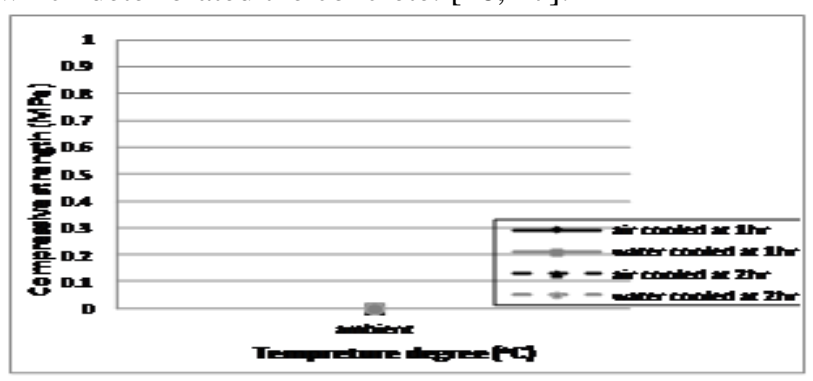

Fig. 12: Effect of elevated temperature and cooled regime on compressive strength for mixture S-20\%

Published By:

Blue Eyes Intelligence Engineering

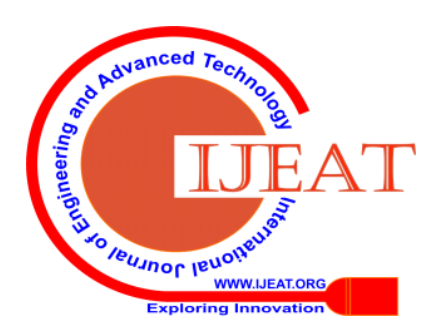


Table-X: Effect of elevated temperature on compressive strength

\begin{tabular}{|c|c|c|c|c|c|c|c|c|c|c|c|c|c|}
\hline \multirow{3}{*}{ Mixture } & \multicolumn{13}{|c|}{ Compressive strength (MPa) } \\
\hline & \multirow{2}{*}{$\begin{array}{l}\text { Ambient } \\
\text { at (28d) }\end{array}$} & \multicolumn{2}{|c|}{$100^{\circ} \mathrm{C}$} & \multicolumn{2}{|c|}{$300^{\circ} \mathrm{C}$} & \multicolumn{2}{|c|}{$600^{\circ} \mathrm{C}$} & \multicolumn{2}{|c|}{$100^{\circ} \mathrm{C}$} & \multicolumn{2}{|c|}{$300^{\circ} \mathrm{C}$} & \multicolumn{2}{|c|}{$600^{\circ} \mathrm{C}$} \\
\hline & & $1 \mathrm{hr}$ & $2 \mathrm{hr}$ & $1 \mathrm{hr}$ & $2 \mathrm{hr}$ & $1 \mathrm{hr}$ & $2 \mathrm{hr}$ & $1 \mathrm{hr}$ & $2 \mathrm{hr}$ & $1 \mathrm{hr}$ & $2 \mathrm{hr}$ & $1 \mathrm{hr}$ & $2 \mathrm{hr}$ \\
\hline S-20\% & 42 & 48.2 & 46.5 & 41 & 38 & 35 & 31 & 45 & 43 & 39 & 35 & 31 & 30 \\
\hline FA-50\% & 54.5 & 56 & 55 & 68 & 61 & 50 & 49 & 54 & 53 & 61 & 56 & 49 & 43 \\
\hline OPC-20\% & 50 & 55 & 52 & 41 & 40 & 36 & 32 & 53 & 51 & 39 & 37.5 & 34 & 30 \\
\hline
\end{tabular}

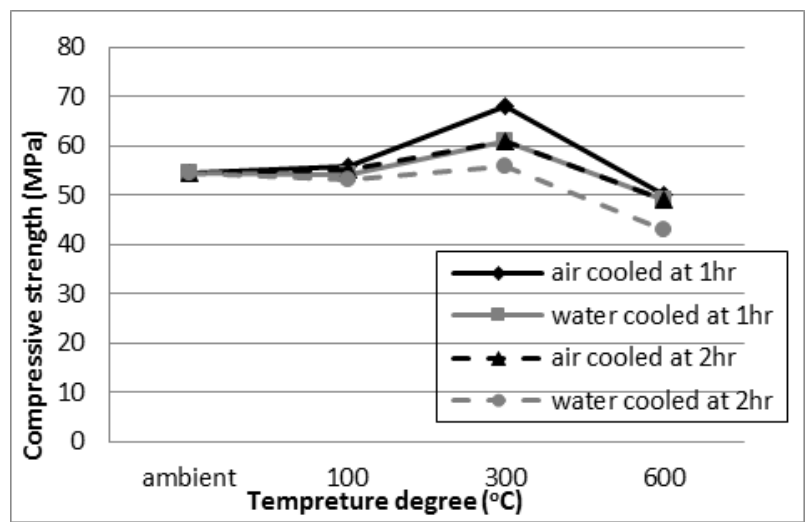

Fig.13: Effect of elevated temperature and cooled regime on compressive strength for mixture FA-50\%

As illustrated in Fig. 14, the mixture OPC-20\% at air cooled regime heating to $100^{\circ} \mathrm{C}$ for one and two hours led to compressive strength increase of about $10 \%$ and $4 \%$, respectively. On the other hand, heating to $300^{\circ} \mathrm{C}$ for one and two hours led to compressive strength reduction of about $18 \%$ and $20 \%$, respectively. Moreover, heating to $600^{\circ} \mathrm{C}$ for one and two hours led to compressive strength loss of about $28 \%$ and $36 \%$, respectively. At water cooled regime heating to $100^{\circ} \mathrm{C}$ for one and two hours led to compressive strength increase of about $6 \%$ and $2 \%$, respectively. On the other hand heating to $300^{\circ} \mathrm{C}$ for one and two hours led to compressive strength loss of about $22 \%$ and $25 \%$, respectively. Moreover, heating to $600{ }^{\circ} \mathrm{C}$ for one and two hours led to compressive strength increase of about $32 \%$ and $40 \%$, respectively. The reduction of compressive strength on concrete may be a result of the release of free water and physically bound water [28, 29]. Siddique and Kaur [30] showed that the similar observation that the residual compressive strength decreased at the blended GGBFS and OPC concrete when the increase in temperature was up to $350^{\circ} \mathrm{C}$.

For all three mixes the increase of compressive strength at $100^{\circ} \mathrm{C}$ may be attributed to complete geopolymerization in the matrix. Moreover, the reduction at water cooled regime compared to air cooled regime may be attributed to the sudden cooling by water form micro cracks resulting from the non-uniform thermal field, in addition coarse aggregates would absorb water and expand [31]

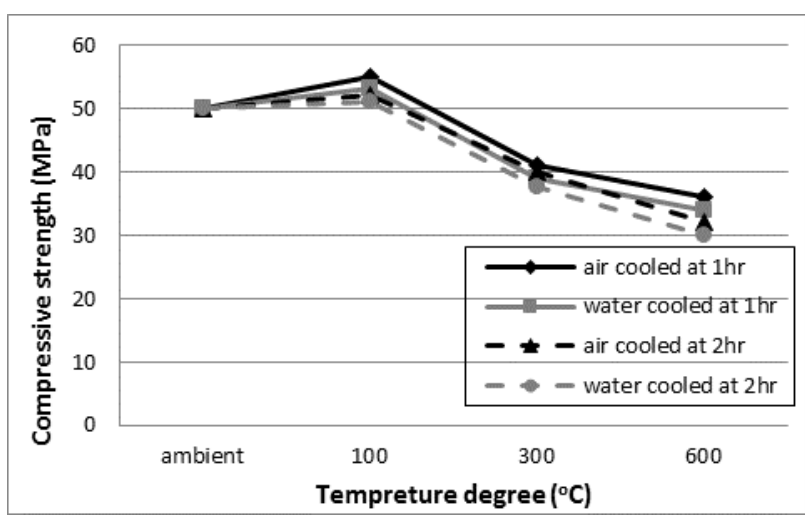

Fig.14: Effect of elevated temperature and cooled regime on compressive strength for mixture OPC-20\%

\section{- Effect of elevated temperature on flexural strength}

Table-XI: effect of elevated temperature on flexural strength

\begin{tabular}{|c|c|c|c|c|c|c|c|c|c|c|c|c|c|}
\hline \multirow{4}{*}{ Mixture } & \multicolumn{13}{|c|}{ flexural strength (MPa) } \\
\hline & \multirow{3}{*}{$\begin{array}{l}\text { Ambient } \\
\text { at (28d) }\end{array}$} & \multicolumn{6}{|c|}{ Air cooled } & \multicolumn{6}{|c|}{ Water cooled } \\
\hline & & \multicolumn{2}{|c|}{$100 \mathrm{oC}$} & \multicolumn{2}{|c|}{$3000 \mathrm{C}$} & \multicolumn{2}{|c|}{$600 \mathrm{oC}$} & \multicolumn{2}{|c|}{$100 \mathrm{oC}$} & \multicolumn{2}{|c|}{$300 \mathrm{oC}$} & \multicolumn{2}{|c|}{$600 \mathrm{oC}$} \\
\hline & & $1 \mathrm{hr}$ & $2 \mathrm{hr}$ & $1 \mathrm{hr}$ & $2 \mathrm{hr}$ & $1 \mathrm{hr}$ & $2 \mathrm{hr}$ & $1 \mathrm{hr}$ & $2 \mathrm{hr}$ & $1 \mathrm{hr}$ & $2 \mathrm{hr}$ & $1 \mathrm{hr}$ & $2 \mathrm{hr}$ \\
\hline S-20\% & 3.9 & 4.5 & 4.2 & 2.8 & 2.4 & 2.4 & 2 & 4.2 & 4 & 2.6 & 2.1 & 2 & 1.8 \\
\hline FA- $50 \%$ & 6.9 & 8.1 & 6.7 & 6.7 & 5.9 & 3.1 & 2.9 & 6.6 & 5.3 & 4.3 & 4.2 & 2.7 & 2.6 \\
\hline OPC-20\% & 4.2 & 4.7 & 4.3 & 4.1 & 3.42 & 3.6 & 3.2 & 4.6 & 4.3 & 4 & 3.3 & 3 & 2.8 \\
\hline
\end{tabular}

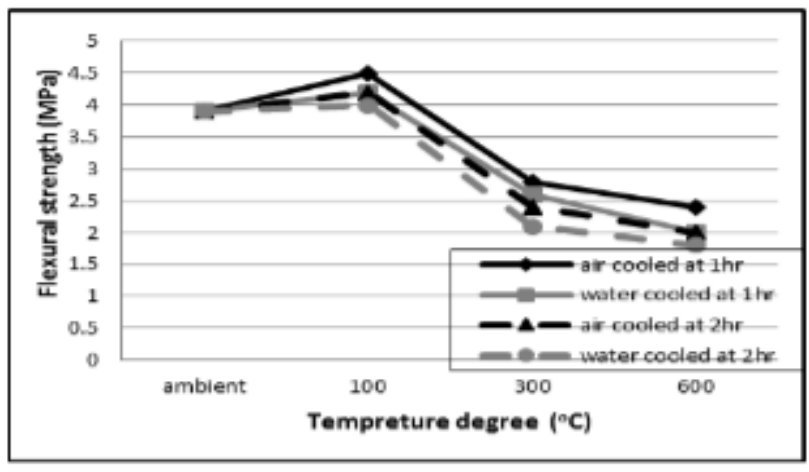

Fig.15: Effect of elevated temperature and cooled regime on flexural strength for mixture S-20\%

As illustrated in Fig. 16, the mixture FA-50\% at air cooled regime heating to $100^{\circ} \mathrm{C}$ for one hour led to flexure strength increase of about $17 \%$ and for two hours led to flexure strength loss of about $3 \%$. On the other hand, heating to $300^{\circ} \mathrm{C}$ for one and two hours led to flexure strength reduction of about $3 \%$ and $14.5 \%$, respectively.

\section{Published By:}

Blue Eyes Intelligence Engineering \& Sciences Publication

(C) Copvriaht: All riahts reserved.

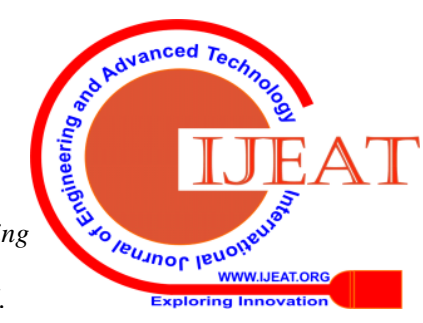


Moreover, heating to $600^{\circ} \mathrm{C}$ for one hour led to flexure strength drop of about $55 \%$ and for two hours led to flexure strength reduction of about $58 \%$. At water cooled regime heating to $100^{\circ} \mathrm{C}$ for one and two hours led to flexure strength reduction of about $4 \%$ and $23 \%$, respectively. On the other hand, heating to $300^{\circ} \mathrm{C}$ for one and two hours led to flexure strength loss of about 38\% and 39\%, respectively. Moreover, heating to $600^{\circ} \mathrm{C}$ for one and two hours led to flexure strength decrease of about $60 \%$ and $62 \%$, respectively.

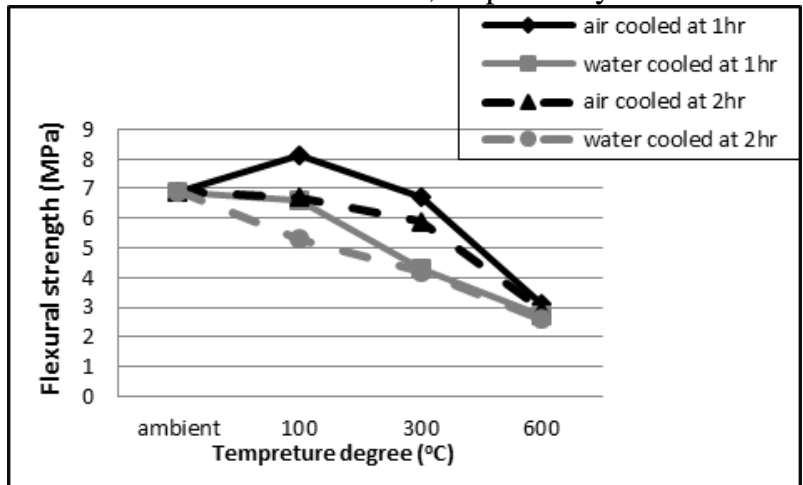

Fig.16: Effect of elevated temperature and cooled regime on flexural strength for mixture FA-50\% samples

As illustrated in Fig. 17, the mixture OPC-20\% at air cooled regime heating to $100^{\circ} \mathrm{C}$ for one and two hours led to flexure strength increase of about $12 \%$ and $2 \%$ respectively. On the other hand, heating to $300^{\circ} \mathrm{C}$ for one and two hours led to flexure strength reduction of about $2 \%$ and $19 \%$, respectively. Moreover, heating to $600^{\circ} \mathrm{C}$ for one and two hours led to flexure strength decrease of about $14 \%$ and $24 \%$, respectively. At water cooled regime heating to $100^{\circ} \mathrm{C}$ for one and two hour led to flexure strength increase of about $10 \%$ and $2 \%$, respectively. On the other hand, heating to $300^{\circ} \mathrm{C}$ for one and two hours led to flexure strength loss of about $5 \%$ and $21 \%$, respectively. Moreover, heating to $600^{\circ} \mathrm{C}$ for one and two hours led to flexure strength decrease of about $29 \%$ and $31 \%$, respectively.

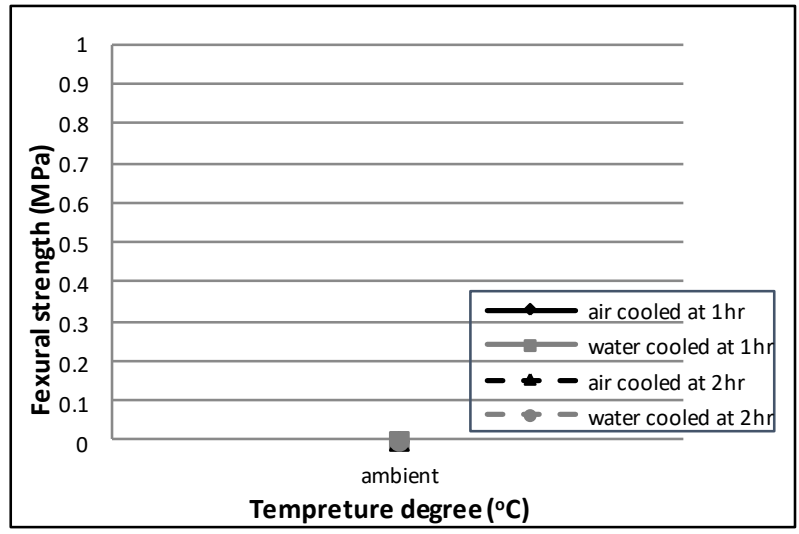

Fig.17: Effect of elevated temperature and cooled regime on flexural strength for mixture OPC-20\% samples.

\section{CONCLUSIONS}

From the analysis and discussion of test results obtained from this research, the following conclusions can be drawn:

1. Higher concentration [molar] of sodium hydroxide solution increased the compressive strength of AAS concrete. Mixture with 12 molar was selected as the basic mixture to study the effect of other parameters.
2. Exposure of samples to steam curing at $60^{\circ} \mathrm{C}$ for 3 days leads to the highest compressive strength for all samples compared with air curing and oven curing.

3. Increasing the sand replacement ratio by slag to $20 \%$ by weight of sand increased the compressive strength by $30 \%$ more than the mixture without sand replacement.

4. Increasing the sand replacement ratio by slag to $50 \%$ by weight of sand decreased the compressive strength by $2 \%$, less than the mixture without sand replacement.

5. Increasing the sand replacement by slag increased the workability.

6. Increasing the slag replacement ratio by fly ash up to $50 \%$ of total base material increased the compressive strength up to $54.4 \mathrm{MPa}$, while slag replacement by $100 \%$ fly ash decreased the compressive strength by $15 \%$ less than the mixture with slag only.

7. Increasing the slag replacement by fly ash increased the workability.

8. Increasing the slag replacement ratio by OPC up to $20 \%$ increased the compressive strength up to 50MPa.

9. Increasing the slag replacement by OPC increased the workability of AAS concrete mixtures.

10. The development rate of compressive strength after 28 days was small compared to its value beyond 28 days.

11. Exposure of samples to elevated temperature at $100^{\circ} \mathrm{C}$ show a certain amount of increase in compressive and flexural strength for all tested mixes regardless of the cooling regime.

12. Exposure of samples to elevated temperature at $300^{\circ} \mathrm{C}$ decreased the compressive and flexural strength of mix S-20\% and OPC-20\% while increased the compressive strength of FA-50\% only regardless of the cooling regime.

13. Exposure of samples to elevated temperature at $600^{\circ} \mathrm{C}$ decreased the compressive and flexural strength of all mixes.

14. The performance of the samples under gradual cooling regime (Air cooling) is better than the sudden cooling regime (water cooling).

15. The performance of samples subject to 1 hour of heating in terms of compressive and flexure strength is better than the samples subject to 2 hour heating.

16. Mixture of slag replacement by $50 \%$ fly ash (FA-50\%) had the best performance in elevated temperature compared with mix S-20\% and OPC-20\%.

\section{REFERENCES}

1. V. M. Malhotra and P. K. Mehta, High-performance, high-volume fly ash concrete: materials, mixture proportioning, properties, construction practice, and case histories: Supplementary Cementing Materials for Sustainable Development Ottawa, 2002.

2. O. E. Gjorv, "Alkali Activation of a Norwegian Granulated Blast-Furnace Slag," Special Publication, vol. 114, pp. 1501-1518, 1989.

3. R. N. Swamy and R. Swamy, Cement replacement materials vol. 3: Surrey University Press Sheffield, 1986.

4. H. K. Shehab, A. S. Eisa, and A. M. Wahba, "Mechanical properties of fly ash based geopolymer concrete with full and partial cement replacement," Construction and building materials, vol. 126, pp. 560-565, 2016. 
5. A. Fernández-Jiménez, J. Palomo, and F. Puertas, "Alkali-activated slag mortars: mechanical strength behaviour," Cement and concrete research, vol. 29, pp. 1313-1321, 1999.

6. S. Al-Otaibi, "Durability of concrete incorporating GGBS activated by water-glass," Construction and building materials, vol. 22, pp. 2059-2067, 2008.

7. D. Perera, O. Uchida, E. Vance, and K. Finnie, "Influence of curing schedule on the integrity of geopolymers," Journal of materials science, vol. 42, pp. 3099-3106, 2007.

8. E. Diaz and E. Allouche, "Recycling of fly ash into geopolymer concrete: creation of a database," in 2010 IEEE Green Technologies Conference, 2010, pp. 1-7.

9. T. Bakharev, "Thermal behaviour of geopolymers prepared using class F fly ash and elevated temperature curing," Cement and Concrete Research, vol. 36, pp. 1134-1147, 2006.

10. D. L. Kong, J. G. Sanjayan, and K. Sagoe-Crentsil, "Comparative performance of geopolymers made with metakaolin and fly ash after exposure to elevated temperatures," Cement and concrete research, vol. 37, pp. 1583-1589, 2007.

11. C. ASTM, "143/C 143M-03 "Standard Test Method for Slump of Hydraulic-Cement Concrete"," Annual Book of ASTM Standards, vol. 4, 2010.

12. B. EN, "12390-3: 2009," Testing hardened concrete. Part, vol. 3, 2009.

13. C. ASTM, "Standard test method for flexural strength of concrete (using simple beam with third-point loading)," in American society for testing and materials, 2010, pp. 19428-2959.

14. G. S. Ryu, Y. B. Lee, K. T. Koh, and Y. S. Chung, "The mechanical properties of fly ash-based geopolymer concrete with alkaline activators," Construction and building materials, vol. 47, pp. 409-418 2013.

15. I. García-Lodeiro, A. Fernández-Jiménez, and A. Palomo, "Variation in hybrid cements over time. Alkaline activation of fly ash-portland cement blends," Cement and concrete research, vol. 52, pp. 112-122, 2013.

16. J. Swanepoel and C. Strydom, "Utilisation of fly ash in a geopolymeric material," Applied geochemistry, vol. 17, pp. 1143-1148, 2002.

17. T. R. Naik, "Sustainability of concrete construction," Practice Periodical on Structural Design and Construction, vol. 13, pp. 98-103, 2008.

18. V. Malhotra, "Introduction: sustainable development and concrete technology," Concrete International, vol. 24, 2002.

19. S. Kumar, R. Kumar, and S. Mehrotra, "Influence of granulated blast furnace slag on the reaction, structure and properties of fly ash based geopolymer," Journal of Materials Science, vol. 45, pp. 607-615, 2010.

20. R. R. Lloyd, J. L. Provis, and J. S. van Deventer, "Microscopy and microanalysis of inorganic polymer cements. 1: remnant fly ash particles," Journal of Materials Science, vol. 44, pp. 608-619, 2009.

21. I. Ismail, S. A. Bernal, J. L. Provis, R. San Nicolas, D. G. Brice, A. R. Kilcullen, et al., "Influence of fly ash on the water and chloride permeability of alkali-activated slag mortars and concretes," Construction and building materials, vol. 48, pp. 1187-1201, 2013.

22. V. Nagendra, D. C. Sashidhar, and D. S. P. Kumar, "Ground Granulated Blast Furnace Slag (GGBS): Effect of Particle Size and Dosage on Compressive Strength with Microstructural Analysis of Concrete," International Journal for Research in Applied Science \& Engineering Technology (IJRASET), ISSN, pp. 2321-9653.

23. A. Palomo and M. Palacios, "Alkali-activated cementitious materials: alternative matrices for the immobilisation of hazardous wastes: Part II. Stabilisation of chromium and lead," Cement and concrete research, vol. 33, pp. 289-295, 2003.

24. A. Palomo and J. L. dela Fuente, "Alkali-activated cementitous materials: Alternative matrices for the immobilisation of hazardous wastes: Part I. Stabilisation of boron," Cement and Concrete Research, vol. 33, pp. 281-288, 2003.

25. C. K. Tennakoon, "Assessment of properties of ambient cured geopolymer concrete for construction applications," Ph. D. thesis, Swinburne University of Technology, 2016.

26. D. L. Kong and J. G. Sanjayan, "Damage behavior of geopolymer composites exposed to elevated temperatures," Cement and Concrete Composites, vol. 30, pp. 986-991, 2008.

27. M. T. Junaid, A. Khennane, and O. Kayali, "Investigation into the Effect of the Duration of Exposure on the Behaviour of GPC at Elevated Temperatures," in MATEC Web of Conferences, 2014, p. 01003.

28. O. Arioz, "Effects of elevated temperatures on properties of concrete," Fire safety journal, vol. 42, pp. 516-522, 2007.

Published By:

Blue Eyes Intelligence Engineering

\& Sciences Publication

(C) Copyright: All rights reserved.

S. Abd Elaziz is a Civil Engineer. She has received her M.Sc. degree from Helwan University in 2020. She graduated from Faculty of Engineering Tanta University in 2011 Engartment, Faculty of Engineering at Mataria, Helwan University, Cairo, Egypt. He has received his Ph.D. Structure Analysis and modeling. Dr. Helmy is active in research and academic supervision on numerous engineering post-graduate students in the field of structure science.

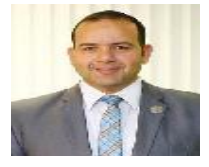

Anwar M. Mohammed is Associate professor, Housing and Building National Research Center. He is a one of assistant Minster of Higher Education. He has received his $\mathrm{Ph} . \mathrm{D}$. degree from Ain Shams University, Cairo, Egypt in 2011. Dr. Anwer is active in research and academic supervision on numerous engineering post-graduate students in the field of material science.

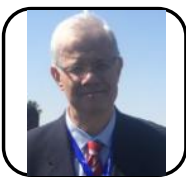

Sherif F.M. Abd Elnaby is a President of Egyptian Russian University. He has received his Ph.D. degree from University of Surrey (UK) in 1992. He obtained his Professorship and became the Vice Dean for student's Affairs of Mataria, Faculty of Engineering of Helwan . He joined the Housing and Building National Research Center of Egypt as the Vice Chairman for Studies and Research Affairs. He was the Director of the Science and Technology. He worked as the Dean Faculty of Engineering of the Egyptian Russian University and the Acting properties of material. prof. Abd Elnaby is active in research and academic supervision on numerous engineering post-graduate students in the field of material science.

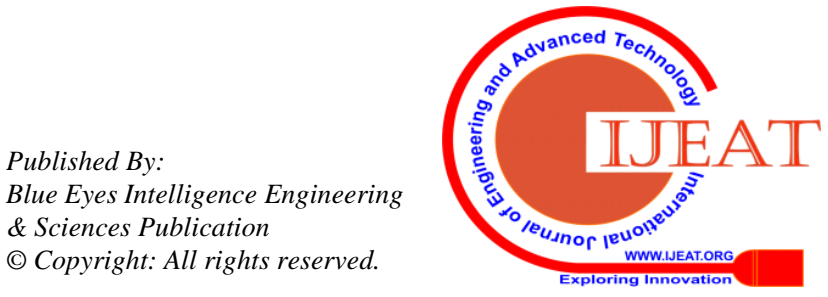

